\title{
MASLAHAH KEBIJAKAN PENCEGAHAN WABAH PANDEMI COVID-19 DALAM ISLAM
}

\author{
St. Samsuduha \\ Dosen Tetap Universitas Muslim Indonesia \\ Email:ssamsuduha1967@gmail.com
}

Tulisan ini mengulas maslahah kebijakan pencegahan wabah pandemi Covid-19 dalam Islam. Maslahah merupakan salah satu tema penting dalam kajian ushul fiqhi. Aspek maslahah menekankan tujuan pemeliharaan asas manfaat kebaikan untuk menjaga syariat dan jiwa manusia. Konsep ini sangat penting dikedepankan dalam menerima dan menjalani segala bentuk kebijakan pencegahan Covid-19. Hasil observasi penulis menunjukkan bahwa beberapa kebijakan yang diterapkan selama pencegahan Covid-19 diantaranya; anjuran menjaga kebersihan, melakukan isolasi mandiri di rumah, menjaga jarak fisik (Physical Distancing), Pembatasan Sosial Berskala Besar (PSBB), dan Pelarangan Shalat Berjamaah di Masjid. Kebijakan-kebijakan ini secara substansial memiliki maslahah dalam Islam karena bertujuan menghindari kemudharatan bahaya Covid-19 yang membahayakan manusia. Dengan demikian, dapat disimpulkan bahwa kebijakan-kebijakan tersebut memiliki maslahah menjaga eksistensi agama Islam, pemeluharaan jiwa dan pemeliharaan keturunan.

Kata Kunci: Maslahah, Kebijakan Pencegahan, Covid-19

\section{A. Pendahuluan}

Dunia sedang menghadapi wabah pademi Covid-19. Berawal dari Wuhan China, wabah Covid-19 menular melalui manusia hingga menggemparkan seluruh negara di dunia sepanjang sejarah umat manusia. Konsekuensi dari merebaknya virus ini melumpuhkan seluruh sektor vital seperti ekonomi, politik, sosial, bahkan agama.

Umat manusia mengalami guncangan, terlebih ketika seluruh tempat ibadah ditutup. Umat Islam juga merasakan hal yang sama mengguncang ketika masjid dianjurkan ditutup untuk sementara selama penanganan wabah pandemi covid-19 ini. Tarikmenarik pendapat terjadi ketika dilakukan peniadaan shalat Jum'at, hal ini sangat menyita perdebatan di kalangan masyarakat muslim, khususnya di Kota Makassar. Pelarangan ibadah secara berjamah ini kemudian secara tegas dilegitimasi dengan fatwa Majelis Ulama Indonesia.

Selain pembatasan ibadah tersebut, masyarakat juga dianjurkan untuk mengisolasi diri di rumah selama berlangsungnya penanganan pandemi covid-19, untuk menunjang percepatan penanganan pandemi ini kemudian diterapkanlah kebijakan pembatasan sosial atau social distancing. Hal ini dimaksudkan untuk memutus matarantai penyebaran covid-19 yang menular begitu massif antara manusia.

Data masyarakat yang tertular Covid-19 sejak awal menunjukkan proses peningkatan ke angka yang mengkhawatirkan. Update data Selasa, 28 April 2020 untuk skala Provinsi Sulawesi Selatan menunjukkan ODP sebanyak 3.751 orang dengan rincian sebanyak 1.124 orang dalam proses pemantauan dan 2.657 orang selesai pemantauan. Selanjutnya untuk PDP sebanyak 781 orang dengan rincian 245 orang masih dalam perawatan, 455 dinyatakan sembuh dan pulang dan 81 orang meninggal. 
Pasien yang dinyatakan Positif saat ini sebanyak 253 orang dengan rincian 301 orang dirawat, 115 orang dinyatakan sembuh dan 37 orang meninggal. ${ }^{1}$ Berdasarkan data tersebut, Kota Makassar merupakan wilayah terdampak paling tinggi sehingga diberlakukan kebijakan PSBB atau social distancing dalam skala besar.

Kebijakan-kebijakan tersebut, untuk saat ini, merupakan upaya terbaik pencegahan wabah. Islam telah lama membekali ummatnya dalam menghadapi wabah penyakit yang berbahaya melalui tindakan Rasulullah yang sangat berkontribusi secara universal hingga hari ini. Umat Islam dianjurkan untuk tidak memasuki suatu wilayah yang mengalami wabah yang dapat dipandang sebagai pembatasan sosial skala besar, dan apabila umat Islam berada dalam suatu wilayah yang mengalami wabah juga dianjurkan untuk tidak meninggalkan tempat tersebut yang dapat dipandang sebagai isolasi mandiri di rumah. Banyak maslahah dan hikmah dari anjuran semacam ini diantaranya untuk keselamatan diri sendiri dan tidak membahayakan keselamatan orang lain yang dapat diberlakukan saat ini.

Selama masa penanganan wabah pandemi Covid-19, tuntunan ajaran Islam sangat penting diperhatikan. Memang di satu sisi pelarangan ibadah shalat berjamah di masjid tentu menjadi hal yang sangat menyedihkan, terlebih dalam masa ramadhan $1441 \mathrm{H}$ ini, namun informasi lain dari Rasulullah juga harus menjadi perhatian ummat Islam untuk mengambil maslahah untuk lebih waspada terhadap diri dan keluarga selama masa wabah yang semakin meningkat.

Berdasarkan penjelasan tersebut di atas, seiring peningkatan penularan wabah Covid-19 sangat penting mengambil maslahah dari kebijakan-kebijakan pencegahan yang diberlakukan Pemerintah dan Majelis Ulama Indonesia. Setiap kebijakan pencegahan Covid-19 merupakan ikhtiar terbaik yang tentunya memiliki maslahah untuk ummat Islam, sehingga harus diikuti demi keselamatan diri dan tidak membahayakan orang lain. Berdasarkan penjelasan tersebut, penulis tertarik mengulas maslahah kebijakan pencegahan covid-19 yang diberlakukan untuk memperoleh wawasan berkaitan dengan kebijakan tersebut dalam perpektif Islam. Berdasarkan pendahuluan di atas, maka rumusan masalah penulisan ini adalah "Bagaimanakah Masalahah Kebijakan Pencegahan Wabah Pandemi Covid-19 dalam Islam?”

\section{B. Pembahasan}

\section{Maslahah dalam Islam}

Maslahah merupakan salah satu tema penting dalam pembahasan ushul fiqhi. Maslahah secara sederhana dapat dimaknai manfaat dari suatu tindakan yang dilakukan. Salah satu defenisinya secara terminologis dikemukakan oleh Harun (2009: 24) bahwa maslahah merupakan mengambil suatu manfaat dan menolak bahaya atau mudharat dengan tujuan memelihara syara' atau hukum Islam. Dengan demikian, hakikat dasar maslahah ialah dilakukan semata-mata mengambil suatu manfaat dari tindakan yang dilakukan dengan niat utama menjaga syariat Islam dan pemeliharaan jiwa.

Hakikat maslahah dapat ditelusuri dari pendapat para Ulama diantaranya dikemukakan oleh Al-Khawarizmi (Zuhaili, 1986: 757) bahwa maslahah yaitu memelihara tujuan hukum Islam dengan menolak bencana atau kerusakan yang merugikan dari makhluk (manusia). Salanjutnya, Al-Buthi (1992: 27) menjelaskan

\footnotetext{
Data Informasi Penanggulangan Covid-19 Kota Makassar, diakses dari https://infocorona.makassar.go.id/ pada tanggal 28 April 2020.
} 
bahwa maslahah merupakan suatu manfaat yang dimaksudkan oleh syari' untuk kebaikan manusia berupa memelihara agama, jiwa, akal, keturunan dan harta.

Berdasarkan penjelasan tersebut di atas, dapat dikemukakan bahwa maslahah merupakan upaya menolak bahaya untuk mengambil manfaat tertentu demi kelangsungan syariat Islam, keselamatan jiwa, keturunan, dan harta benda yang dilakukan oleh manusia. Oleh karena itu, proses mengambil maslahah dapat dikatakan sebagai ikhtiar yang dilakukan dengan berbagai cara atau tindakan untuk mengambil manfaat.

a. Jenis-Jenis Maslahah

Secara konseptual, maslahah dapat dibedakan menjadi beberapa macam berdasarkan rumusan dalam beberapa literatur, sebagaimana penjelasannya diuraikan sebagai berikut.

1) Maslahah berdasarkan Tingkat Kebutuhan

Maslahah berdasarkan kebutuhan dapat dibedakan menjadi tiga macam, yaitu; maslahah dharuri, maslahah hajiyah, maslahah tahsiniyah. Jauhar (2009: xvi) menjelaskan tiga macam yaitu, Pertama; maslahah dharurui merupakan kemaslahatan yang manusia butuhkan untuk menopang kehidupan. Lebih lanjut dijelaskan bahwa apabila salah satu prinsip tersebut tidak ada, maka kehidupan manusia tidak sempurna seperti menjauhi larangan Allah berarti maslahah pada tingkat dharuri, seperti misalnya larangan murtad sebagai upaya pemeliharaan agama, larangan membunuh sebagai pemeliharaan jiwa, tidak meminum khamar untuk memelihara akal, larangan berzina untuk memelihara keturunan, dan larangan mencuri untuk memelihara harta.

Kedua; maslahah hajiyah merupakan kemaslahatan pemenuhan kebutuhan pokok secara tidak langsung, namun proses pemenuhannya berlangsung ke arah tersebut dalam hal memberikan kemudahan bagi pemenuhan kehidupan manusia. Dan, Ketiga; maslahah tahsiniyah merupakan ciri kemaslahatan yang dipenuhi untuk melengkapi serta keidahan hidup manusia.

\section{2) Maslahah berdasarkan Eksistensi}

Maslahah berdasarkan eksistensinya dapat dibagi menjadi tiga macam, yaitu maslahah mutabarak, maslahat mulhah, maslahah mursalah. Tiga macam mursalahan ini dijelaskan sebagai berikut.

Mursalah mutabarak termasuk mursalah yang tegas diakui dalam Islam. Efendi (2005: 129) mengemukakan bahwa jenis maslahah mutabarak merupakan maslahah yang jelas diakui syariat serta telah ditetapkan ketentuan hukum dalam merealisasikannya. Berkaitan dengan maslahah mulqhah, Zaydan (2009: 187) mengemukakannya sebagai maslahah yang tidak terakui dalam syara. Hal ini melalui nash langsung. Jenis maslahat ini dengan sendirinya ditolak berdasar dalil menunjukkan pertentangan serta hanya dianggap baik oleh manusia saja.

Maslahah yang ketiga yakni maslahah mursalah dapat dipahami sebagai maslahah yang sesuai dengan tujuan syariat. Jenis maslahah ini dapat dijadikan dasar pijakan mengimplementasikan kebaikan untuk menghindari kerusakan atau kemudharatan. 
Umat Islam hidup menetap di lingkungan masyarakat yang berbeda-beda, sehingga perbedaan situasi dan kondisi mengharuskan kesamaan tujuan memperoleh manfaat tertentu selama tidak bertentangan dengan ajaran syariat Islam.

3) Maslahah berdasarkan Fleksibilitas

Maslahah diterapkan secara fleksibel, tentunya sangat bergantung situasi dan kondisi. Meskipun demikian ada maslahah tertentu yang tidak bisa diubah untuk kebaikan seorang muslim. Hal ini sebagaimana dijelaskan Tamrin (2007: 118-125) bahwa maslahah berubah karena waktu dan lingkungan. Dicontohkannya seperti hal muamalah dan kebiasaan atau al-urf. Sedangkan maslahah yang tidak berubah dicontohkan seperti halnya ibadah. Pada bagian penjelasan lain dijeslankan bahwa secara syariah kemaslahatan harus didahulukan berupa kepentingan umum karena menjadi bagian penting tujuan syara' dalam hal terciptanya kepentingan umum.

\section{b. Tujuan Pemeliharaan Maslahah}

Penjelasan tersebut di atas menunjukkan aspek penting maslahah dalam kehidupan ummat manusia yang berlandaskan pada nilai unversal Islam untuk mewujudkan kebaikan bagi manusia. Meskipun telah disinggung sebelumnya, ulasan pada bagian ini untuk memberikan penjelasan secara rinci bahwa tujuan menjaga maslahah berkaitan dengan beberapa pemeliharaan dalam Islam sebagai berikut.

\section{1) Pemeliharaan Agama}

Syariat agama merupakan hal yang paling utama bagi seseorang mengambil maslahah bagi dirinya di dunia dan akhirat. Berkaitan dengan pemerilahaan agama ini, Djamil (1997: 128) menjelaskannya dalam konteks dhururiyat, hijiyat dan tahsiniyat. Dalam konteks dhururiyat memelihara agama seperti melakukan shalat lima waktu, karena jika tidak dilakukan akan membahayakan diri dan eksistensi agama. Pada koneks hijiyat, maslahah pemeliharaan agama dicontohkannya dengan melaksanakan ketentuan agama untuk menghindari kesulitan, misalnya jamak dan ashar bagi orang yang bepergian atau musafir, yang jika tidak dilakukan akan mempersulit orang yang tidak melakukannya. Selanjutnya dalam konteks tahsiniyat, yaitu upaya menutup aurat dan menjaga akhlak dalam mengambil maslahah pemeliharaan agama.

Penjelasan tersebut di atas menunjukkan bahwa mengambil maslahah dalam hal pemeliharaan agama merupakan inti yang sangat penting. Hal ini dilakukan untuk mengambil manfaat dari ajaran agama yang secara hakiki sesuai dengan apa yang manusia butuhkan. Selain itu, upaya mengambil maslahah dalam konteks ini pula untuk menjaga eksistensi agama Islam di muka bumi yang dapat memberikan jaminan maslahah keselamatan di akhirat kelak.

\section{2) Pemeliharaan Jiwa}

Pemeliharaan jiwa merupakan hak asasi manusia untuk hidup sesuai dengan harkat dan martabatnya. Djamil (1997: 128) menjelaskan dalam konteks dhururiyat, pemeliharaan jiwa ini sebagai upaya memenuhi kebutuhan pokok manusia dalam kehidupan. Tidak terpenuhinya kepubutuhan pokok akan mengancam eksistensi 
manusia itu sendiri. Secara hijiyyat, proses memenuhi kebutuhan pokok harus dilakukan dengan cara yang baik atau halal. Hal ini jika tidak dilakukan tidak akan mengancam eksistensi manusia, namun akan mempersulit hidupnya kelak. Secara tahsiniyyat, pemeliharaan jiwa ada pada persoalan etika, misalnya etika makan. Jika tidak dilakukan tidak mengancam eksistens jiwa manusia, namun akan mempesulit manusia itu sendiri.

\section{3) Pemeliharaan Keturunan}

Djamil (1997: 130) menjelaskan hal ini sebagai suatu proses pelestarian umat manusia melalui pengembangan populasi. Pemeliharaan ini akan memungkinkan manusia tetap hidup dan berkembang. Dilihat dari aspek dhururiyat, maka disyariatkan menikah untuk terhindar dari perzinahan dan jika tidak dilakukan akan mengancam eksistensi keturunan manusia. Pada aspek hijiyyat, berkaitan dengan penyebutan jumlah mahar dan talak, jika tidak dilakukan tidak mengancam eksistensi manusia tetapi mempersulit kehidupan manusia. Sedangkan pada aspek tahsiniyyat, proses pemeliharaan ini ditempuh melalui khitbah dan walimah. Apabila hal ini tidak dilakukan sama sekali tidak mengancam eksistensi keturunan, juga tidak mempersulit manusia itu sendiri dalam kehidupannya.

Berdasarkan penjelasan tersebut dapat dipahami bahwa berbagai kebijakan selama penanganan Covid-19 memiliki maslahah yang berkaitan dengan maslahah dhurui yakni pemeliharaan agama dan perlindungan jiwa manusia. Berbagai kebijakan yang diterapkan juga penting dipatuhi demi maslahah kepentingan umum secara bersama. Meskipun dirasakan konsekuensi terhadap pemasukan harta dan sebagainya, namun berbagai kebijakan tersebut memiliki maslahah yang lebih besar. Rasulullah telah menganjurkan untuk menghindari wilayah terdampak wabah dan tidak meninggalkan wilayah tersebut juga memiliki maslahah bagi umat Islam. Untuk sejumlah kasus wabah dan penerapan kebijakan yang bermasalah bagi agama dan ummat Islam juga terjadi sepanjang pertumbuhan Islam, sejak zaman Rasulullah dan para sahabat hingga hari ini sebagaimana penjelasannya sebagai berikut.

\section{4) Wabah dalam Sejarah Islam}

Wabah penyakit merupakan musibah yang paling purba yang sudah sejak lama menjangkiti manusia. Beberapa catatan penting menunjukkan bahwa wabah penyakit juga terjadi di masa Rasulullah, salah satunya wabah lepra. Wabah juga terjadi di masa para sahabat. Putri (historia.id) mengutip Michael Walters Dols, salah satu sejarawan Amerika Serikat, bahwa wabah Amwas menyerang tentara Arab di Amwas, Emmaus, yang berada di wilayah Jerusalem. Serangan wabah ini terjadi pada periode Kekhalifahan Umar Bin Khatab pada tahun 638-639.

Lebih lanjut dijelaskan bahwa wabah ini (Amwas) terjadi kurang lebih dua kali selama Muharram dan Safar dan menelan 25.000 korban jiwa tentara muslim secara meluas di seluruh Suriah, Irak dan Mesir. Selain wabah tersebut juga merebaknya wabah yang disebut Al-Jarif pada tahun 688-689 menyerang Basrah, Irak. Wabah ini menelan puluhan ribu korban jiwa dalam tiga hari berturut-turut.

Merebaknya wabah penyakit juga berdampak pada pembatalan pelaksanaan ibadah haji. Hal ini dapat dilihat pada penjelasan yang diuraikan oleh Fairuz (2020) bahwa pada tahun 1813 ibadah haji dibatalkan akibat wabah kolera yang menelan korban sekitar 
8.000 penduduk Hijaz. Wabah kemudian berlangsung pada tahun 1831 dengan merebaknya wabah kolera dari India sampai ke Makkah sehingga menewaskan tiga perempat jamaah haji.

Selanjutnya pada masa periode tahun 1837-1858 haji dihentikan sebanyak tiga kali dalam rentang waktu dua puluh tahun. Wabah mengakibatkan jamaah haji tidak bisa ke Makkah. Setelah itu, pada tahun 1837 wabah kolera kembali mewabah di Makkah sehingga haji kemudian dihentikan sampai tahun 1840. Wabah kolera ini juga kembali menyebar pada tahun 1846 hingga menelan korban jiwa 15.000 orang dan muncul lagi pada tahun 1865 dan 1883 .

Wabah kolera merupakan penyakit yang selalu muncul dalam skala global. Fairuz (2020) lebih lanjut menjelaskan bahwa pandemi kolera ini sampai ke Makkah pada tahun 1858 dan menyebabkan jamaah asal Mesir melarikan diri secara massal ke pantai Laut Merah Mesir dan menjadi tempat mereka ditahan dan dikarantina untuk pengobatan dan pemulihan. Dalam kurun waktu tahun 1899-1923, wabah kolera menjadi wabah mematikan. Lebih dari 34.00 orang tewas di Mesir hanya dalam tiga bulan saja dan diperkirakan jamaah haji meninggal di Makkah pada tahun 1902 sebanyak 4.000 jamaah. Hal ini berlanjut pada tahun 1907-1908 sebanyak 20.000 peziarah meninggal karena kolera selama musim haji.

Berdasarkan penjelasan tersebut, menunjukkan betapa wabah penyakit merupakan peritiwa yang berbahaya yang menelan banyak korban jiwa. Wabah penyakit yang menular terjadi setiap saat dalam kehidupan umat manusia yang berdampak secara serius secara global. Hal tersebut juga berdampak pada praktik ibadah umat Islam seperti penghentian dan pembatalan ibadah haji meskipun termasuk rukun Islam yang wajib hukumnya dilaksanan. Namun, karena situasi yang tidak kondisufi karena wabah ibadah haji dapat ditiadakan untuk sementara demi mengambil maslahah penyelatan umat Islam yang terdampak wabah.

Fakta pengehentian ibadah umat Islam ini juga terjadi ketika wabah Covid-19 mulai merebak saat ini. Hal ini dapat dilihat pada penghentian shalat berjamah yang berlaku hingga pelaksanaan ramadhan $1441 \mathrm{H}$. Covid-19 telah merenggut banyak nyawa, sehingga para ulama berijtihad mengeluarkan fatwa peniadaan shalat berjamaah di masjid, termasuk shalat jumat diganti dengan shalat dzuhur di rumah. Pentingnya fatwa ini diimplementasikan untuk penanganan Covid-19 dan terutama sebagai kebijakan perlindungan umat Islam dari wabah sesuai anjuran Rasulullah.

\section{5) Anjuran Menghadapi Wabah dalam Islam}

Segala macam penyakit haruslah diyakini datang dari Allah semata-mata untuk mencoba keimanan umat manusia. Selain itu, terkadang wabah penyakit juga datang sebagai bentuk al-bala' akibat ulah manusia melakukan berbagai kerusakan di muka bumi, sebagaimana firman Allah sebagai berikut.

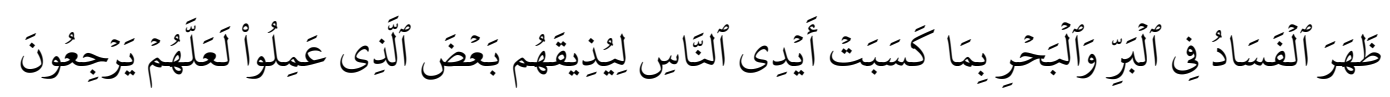

Terjemahannya; "Telah nampak kerusakan di darat dan di laut disebabkan karena perbuatan tangan manusi, supaya Allah merasakan kepada mereka sebahagian dari 
(akibat) perbuatan mereka, agar mereka kembali (ke jalan yang benar)" (QS. AlRûm [30]: 41) ${ }^{2}$

Covid-19 yang mewabah di Wuhan dan saat ini telah merebak di seluruh dunia memungkinkan berkaitan dengan ulah manusia, oleh karena itu umat Islam perlu memerhatikan ajaran Islam berkaitan dengan wabah ini. Banyak dalil lainnya di dalam Al-Qur'an yang dapat dipelajari untuk mengambil pelajaran penting maslahan untuk manusia. Selain itu, terdapat sabda Rasulullah yang penting pula menjadi pusat perhatian umat Islam menyikapi masalah wabah. Dalil tersebut dapat diuraikan berikut.

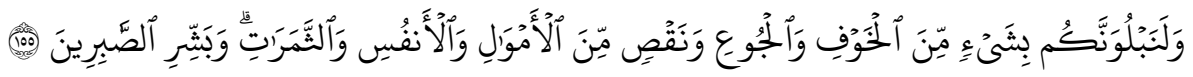

Terjemahannya; "Dan sungguh akan Kami berikan cobaan kepadamu, dengan sedikit ketakutan, kelaparan, kekurangan harta, jiwa dan buah-buahan. Dan berikanlah berita gembira kepada orang-orang yang sabar”. (QS. Al Baqarah [2]: $155)^{3}$

Wabah Covid-19 haruslah dipandang sebagai cobaan. Ciri-ciri cobaan dalam ayat tersebut dapat dilihat dalam realitas saat ini yaitu wabah ini telah menmbulkan ketakutan kepada seluruh umat manusia di dunia karena penularannya kepada manusia yang cepat dan mematikan. Di beberapa media juga diberitakan berbagai kasus kelaparan di Indonesia akibat wabah ini karena kurangnya persediaan makanan selama mengisolasi diri secara mandiri.

Konsekuensi ekonomi juga dirasakan dan angka kematian akibat wabah Covid-19 secara nasional sangat memprihatinkan, terlebih wafatnya tenaga medis yang berjuang di garda paling depan penanggulangan wabah Covid-19. Menyikapi hal ini, Rasulullah juga menganjurkan umatnya menghindari wabah sebagaimana sabdanya, sebagai berikut.

Dari Nabi saw sesungguhnya beliau bersabda: "Jika kamu mendengar wabah di suatu wilayah, maka janganlah kalian memasukinya. Tapi jika terjadi wabah di tempat kamu berada, maka jangan tinggalkan tempat itu." (HR. al-Bukhari) ${ }^{4}$

Nabi saw. bersabda: "Amal-amal umatku disampaikan kepadaku, amal baik atau amal buruknya. Kutemukan diantara amal terbaik adalah menyingkirkan hal membahayan dari jalan. Dan kutemukan diantara amal terburuknya adalah dahak di masjid yang tidak dibersihkan" (HR Muslim) ${ }^{5}$

\footnotetext{
2 dalam Al-Qur'an dan Terjemahnya (Jakarta: Depag RI, 1995), h. 647

${ }^{3}$ dalam Al-Qur'an dan Terjemahnya (Jakarta: Depag RI, 1995), h. 39

${ }^{4}$ dalam Fatwa Majelis Ulama Indonesia Nomor 14 Tahun 2020 tentang Penyelenggaran Ibadah dalam Situasi Terjadi Wabah Covid-19, diakses dari https://mui.or.id/ pada tanggal 29 April 2020.

5 Ibid, h. 5
} 
Barang siapa yang mendengar azan wajib baginya sholat berjamaah di masjid, kecuali ada uzur". Para sahabat bertanya: “Apa maksud uzur ?”. Jawab Rasulullah SAW: "Ketakutan atau sakit." (HR. Abu Daud) ${ }^{6}$

Hadits tersebut menunjukkan bagaimana Rasulullah menganjurkan sikap protektif terhadap keadaan wabah di suatu wilayah. Hadits inilah yang palih dikutip oleh banyak kalangan melakukan edukasi penanggulangan Covid-19 akhir-akhir ini. Sabda tersebut juga dapat dimaknai sebagai anjuran menahan diri untuk tidak bepergian ke tempattempat yang terpapar wabah, dan bagi mereka yang sedang berada dalam wilayah terpapar penting tidak meninggalkan tempat tersebut atau mengisolasi diri selama wabah berlangsung. Dengan demikian, hadits tersebut kontekstual dengan kondisi umat hari ini yang mengisolasi diri di rumah untuk mengambil maslahah untuk dirinya dan bagi orang lain.

\section{6) Kebijakan Pencegahan Wabah Covid-19}

Covid-19 atau Corona Virus Disease 2019 merupakan wabah penyakit terbesar yang menginfeksi umat manusia di abad moderen. Penjelasan jenis wabah ini mendominasi perhatian berbagai media akhir-akhir ini. Dijelaskan (https://www.google.com) bahwa penyakit ini merupakan jenis baru yang belum pernah diidentifikasi pada manusia. Virus ini menyerang saluran pernapasan seperti flu dengan berbagai gejala seperti batuk, demam dan yang terburuk ialah menimbulkan kejala pneumonia. Tindakan preventif yang paling sederhana pencegahannya yaitu dengan mencuci tangan secara rutin dan menghindari sentuhan wajah. Pola penyebaran virus ini melalui kontak dengan orang yang telah terinfeksi saat batuk atau bersin atau tetes air liur atau cairan hidung orang yang terinfeksi.

Sejak awal penyebarannya, berbagai kebijakan edukasi ke masyarakat telah di lakukan mulai dari menjaga kebersihan dengan mencuci tangan secara teratur setelah beraktivitas, menjaga jarak (social distancing) minimal satu meter dengan orang lain, isolasi mandiri di rumah selama pandemi, menghindari kontak fisik jabat tangan dan lain sebagai atau yang disebut (physical distancing), hingga pemberlakukan kebijakan resmi lainnya seperti Pembatasan Sosial Berskala Besar (PSBB). Beberapa kebijakan edukatif ini diaksudkan untuk memutus matarantai penyebaran Covid-19. Jika dicermati, kebijakan-kebijakan tersebut memiliki maslahah dalam Islam.

\section{a. Menjaga Kebersihan}

Salah satu sebab penyakit mudah menyebar karena aspek kebersihan diri maupun lingkungan yang tidak terjaga dengan baik. Lingkungan yang kotor merupakan pemandangan yang mudah ditemukan di lingkungan masyarakat. Oleh karena itu, adanya Covid-19 harus dipahami sebagai koreksi kelalaian manusia terhadap kebersihan diri dan kebersihan lingkungan. Aspek kebersihan merupakan salah satu hal penting yang ditekankan dalam Islam. Bahkan, kebersihan merupakan bagian dari iman yang menjadi aspek kunci pelaksanaan ibadah wajib dalam Islam. Allh Swt. juga mencintai orangorang yang mensucikan diri sebagaimana firmannya sebagai berikut.

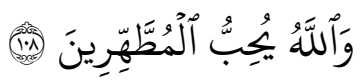

${ }^{6}$ Ibid, h. 6 
Terjamahanya; ... Dan Allah menyukai orang-orang yang bersih (QS. At-Taubah [9]: $108)^{7}$

Menjaga kebersihan diri merupakan tindakan preventif yang dilakukan untuk mencegah penyebaran Covid-19. Aspek kebersihan ini utamanya ditekankan pada kebersihan tangan yang harus dibersihkan dengan sabuh maupun cairan berbasis alkohol. Maslahah dari tindakan ini ialah untuk membunuh virus jika seseorang telah melakukan kontak jabat tangan dengan orang lain termasuk memegang sesuatu selama berada di tempat umum. Hal lainnya yang penting dilakukan ialah tidak menyentuh hidung dan bagian wajah karena potensial memindahkan virus yang menempel di tangan. Untuk bagian wajah ini penting kiranya menjaga wudhu sebelum maupun sesudah beraktivitas di luar. Dengan demikian, manfaat lain dari aspek menjaga kebersihan memiliki maslahah menjalankan tuntunan syariat agama Islam sehingga seorang muslim yang menjaga kebersihan diri senantiasa dicintai Allah Swt.

\section{b. Isolasi Mandiri di Rumah}

Sejak awal, suara yang menganjurkan setiap orang berada di rumah saja merupakan harapan melindungi diri dari terpaparnya wabah Covid-19. Isolasi mandiri penting dilakukan oleh orang yang sehat maupun yang baru pulang dari melakukan perjalanan di suatu tempat yang telah terpapar. Maslahah dari isolasi mandiri ialah memastikan seseorang sehat dan terlindungi dari paparan virus. Selain itu, bagi orang yang baru pulang dari suatu perjalanan akan sangat memiliki maslahah untuk memastikan dirinya sehat juga tidak membahayakan orang lain. Isolasi mansiri di rumah merupakan suatu proses identifikasi dan pengamatan terhadap gezalah Covid-19 pada orang yang melakukan isolasi mandiri di rumah.

\section{c. Menjaga Jarak Fisik (Physical Distancing)}

Jarak fisik merupakan upaya pemutusan penularan virus minimal satu meter. Maslahah yang dapat diambil dari hal ini ialah menjaga diri dari penularan melalui bersin orang yang terinfeksi. Fakta menunjukkan bahwa penuliran banyak terjadi melalui batuk maupun bersin. Tetes cairan orang yang bersin sangat berbaha bila sudah terinfeksi Covid-19. Jadi, hal tidak dimaksudkan untuk memutuskan tali silaturahmi sesama manusia, namun demi maslahat bersama dalam ranggka pencegahan penularan Covid19.

\section{d. Pembatasan Sosial Berskala Besar (PSBB)}

Pembatasan Sosial Berskala Besar (PSPB) merupakan kebijakan yang secara resmi dikeluarkan oleh Pemerintah dalam upaya penanggulangan Covid-19. Dalam Permenkes Nomor 9 Tahun 2020 (Kemenkes, 2020) dijelaskan bahwa PSPB yaitu pembatasan kegiatan tertentu penduduk dalam suatu wilayah yang diduga terinfeksi Covid-19 sedemikian rupa untuk mencegah kemungkinan penyebaran Covid-19.

Jika diamati, penerapan kebijakan ini termasuk memiliki kelonggaran karena berbeda dengan penerapan pembatasan sosial di nagara lainnya. Pembatasan yang paling ditekankan adalah kerumunan orang pada suatu tempat, termasuk pertokoan di pasar, mal, hotel dan lain sebagainya yang memungkinkan memicu berkumpulnya orang

\footnotetext{
${ }^{7}$ dalam Al-Qur’an dan Terjemahnya (Jakarta: Depag RI, 1995), h. 299
} 
ditutup. Maslahah kebijakan ini sangat besar terhadap perlindungan warga negara dan menekan penularan Covid-19. Maslahah lainnya ialah upaya mengantisipasi dapak buruk yang dapat ditimbulkan oleh wabah ini pada aspek politik, ekonomi, sosial. Budaya, pertahanan dan keamanan, serta kesejahteraan masyarakat di Indonesia. Masyarakat yang disiplin mengikuti intruksi kebijakan ini berarti berpartisipasi dalam pemulihan keadaan dari wabah Covid-19.

e. Pelarangan Shalat Berjamaah di Masjid

Kebijakan pelarangan ibadah shalat secara berjamaah merupakan keputusan yang paling kontrafersial karena mengundang prokontra di tengah masyarakat. Di beberapa tempat terdapat reaksi protes, bahkan ada yang tidak mengindahkan kebijakan ini, meskipun rujukan kebijakan ini adalah Fatwa Majelis Ulama Indonesia. Reaksi kontras ini terjadi karena wawasan dan pemahaman masyarakat terhadap Fatwa yang belum tersosialisasi secara menyeluruh.

Fatwa Majelis Ulama Indonesia Nomor 14 Tahun 2020 mengatur Penyelenggaraan Ibadah dalam Situasi Terjadi Wabah Covid-19 menunjukkan perhatian penuh Ulama terhadap umat Islam sekaligus menjadi Ijma para Ulama yang absah dirujuk sebagai salah satu sumber hukum dalam Islam. Fatwa ini merujuk beberapa dalil Al-Qur'an, AlHadits, dan Qaidah Fiqhiyyah serta memerhatikan pendapat beberapa Ulama terkemuka sebagai berikut.

Pertama; pendapat imam Nawawi dalam Kitab al-Majmu' juz 4 halaman 352 berkaitan dengan gugurnya kewajiban shalat Jum'at, dan Kedua; pendapat Abdullah bin Abdurrahman bin Abu Bakar Bafadhal al-Hadramy al Sa'dy al Madzhajy dalam kitab al-Mukaddimah al-Hadramiyah hal 91 tentang udzur shalat Jum'at dan shalat jama'ah. Seluruh poin ketentuan di dalam fatwa in memiliki maslahah yanng mencakup beberapa jenis maslahah yang telah dibahas sebelumnya, yakni maslahah agama, menjaga jiwa, dan pemeliharaan keturuan dari bahaya Covid-19.

Berdasarkan penjelasan di atas, dapat disimpulkan bahwa kebijakan penanganan Covid-19 memiliki maslahah bagi umat Islam. Maslahah tersebut yaitu untuk menjaga agama, menjaga jiwa, dan pemeliharaan keturunan. Umat Islam yang terhindar dari bahaya wabah ini akan memungkinkan syariat agama Islam tetap berjalan setelah berakhirnya pademi. Umat Islam yang disiplin mengikuti segala kebijakan pemerintah, Fatwa MUI, maupun protokol medis lainnya akan membuat jiwa selamat sehingga mampu memelihara diri dan keturunan.

Maslahah terbesar dari wabah pandemi ini ialah muhasabah diri selama isolasi diri di rumah untuk senantiasa mendekatkan diri kepada Allah dengan perbanyak ibadah, dzikir dan shalawat, doa dan sadaqah untuk tim relawan medis maupun pasien yang diberikan cobaan untuk sembuh serta mendoakan dokter dan perawat yang wafat selama bertugas, terutama doa untuk pasien yang meninggal untuk husnul khatimah di sisi Allah Swt. Semoga Allah Swt secepatnya mengangkan wabah ini dari permukaan bumi untuk maslahah agama yang telah disempurnakan dan diridhainya.

\section{Kesimpulan}

Berdasarkan pembahasan di atas, maka penulis merumuskan beberapa kesimpulan sebagai berikut.

Maslahah dalam Islam termasuk salah satu pembahasan ushul fiqhi. Makna dari maslahah ialah mengambil suatu manfaat dan menolak bahaya atau mudharat dengan tujuan memelihara agama dan keselamatan diri. Di tengah wabah pandemi, maslahah 
berkaitan dengan berbagai kebijakan pencegahan Covid-19. Anjuran berkaitan dengan pentingnya menghindari wabah atau tidak meninggalkan tempat yang tertimpa wabah sudah lama diajarkan oleh Rasulullah, hingga para sahabat pun mempedomaninya. Banyak dalil Al-Qur'an yang dapat dirujuk sebagai peringatan datangnya penyakit serta hadits Rasulullah sebagai dasar bagi umat manusia mengambil maslahah darinya.

Beberapa kebijakan yang saat ini diberlakukan ialah pentingnya menjaga kebersihan, melakukan isolasi mandiri di rumah, menjaga jarak fisik (Physical Distancing), Pembatasan Sosial Berskala Besar (PSBB), dan Pelarangan Shalat Berjamaah di Masjid tentunya memiliki maksud mulia atau maslahah yang bermanfaat untuk agama dan jiwa umat serta bermaslahah untuk memutus matarantai penularan Covid-19.

\section{DAFTAR PUSTAKA}

Al-Buthi, Sa ${ }^{e i d}$ Ramadhan. 1992. Dhawabit Al-Maslahah Fi Al-Syari'ah Al-Islamiyah. Beirut: Mu'assasah Al-Risalah.

Data Informasi Penanggulangan Covid-19 Kota Makassar, diakses dari https://infocorona.makassar.go.id/ pada tanggal 28 April 2020.

Depag. 1995. Al-Qur'an dan Terjemahnya. Jakarta: Depag RI.

Djamil, Fathurrahman. 1997. Filsafat Hukum Islam. Jakarta: Logos Wacana Ilmu.

Efendi, Satria. 2005. Ushul Fiqh. Jakarta: Prenada Media.

Fatwa Majelis Ulama Indonesia Nomor 14 Tahun 2020 tentang Penyelenggaran Ibadah dalam Situasi Terjadi Wabah Covid-19, diakses dari https://mui.or.id/ pada tanggal 29 April 2020.

Harun. 2009. Pemikiran Najmudin At-Thufi tentang Konsep Maslahah sebagai Teori Istinbath Hukum Islam, Jurnal Digital Ishraqi vol.5, 1 Januari-Juni 2009.

Jauhar, Ahmad Al-Mursi Husain. 2009. Maqashid Syariah, Terj. Khimawati, Jakarta: Amzah.

Kemenkes. 2020. Peraturan Menteri Kesehatan Republik Indonesia Nomor 9 Tahun 2020 Tentang Pedoman Pembatasan Sosial Berskala Besar Dalam Rangka Percepatan Penanganan Corona Virus Disease 2019 (Covid-19) Diakses Dari Kukor.Kemkes.Go.Id.

Putri, Risa Herdahita. tth. "Wabah Sejak Zaman Rasulullah." Artikel. Diakses di https://historia.id pada tanggal 29 April 2020.

Zaydan, Abdul Karim. 2009. Ushul Fiqh. Surabaya: Arkola.

Zuhaili, Wahbah. 1986. Ushul Al-Fiqh Al-Islamy, Juz II. Beirut: Dar al-Fikr. 